\title{
X-linked intellectual disability, Stocco Dos Santos type
}

INSERM

\section{Source}

INSERM. (1999). Orphanet: an online rare disease and orphan drug data base. $\underline{X-l i n k e d}$ intellectual disability, Stocco Dos Santos type. ORPHA:85288

X-linked intellectual disability, Stocco Dos Santos type is characterised by severe intellectual deficit with hyperactivity, language delay, congenital hip luxation, short stature, kyphosis and recurrent respiratory infections. Aggressive behaviour and frequent epileptic seizures may also be present. The syndrome has been described in four boys from the same family. Transmission is X-linked and is caused by mutations in the KIAA1202 gene, localised to the Xp11.2 region. 